\title{
Effects of salinity and external proline on seed germination and early growth of Cucumis sativus cv. super ps
}

\author{
FARIBA AMINI", MEHRY ASKARY, FAHIMEH MOHTASHAMI \\ Department of Biology, Faculty of Science, Arak University. Arak, P.O. Box: 38156-8-8349, Iran. `email: f-amini@araku.ac.ir, \\ faribaamini976@gmail.com
}

Manuscript received: 14 August 2018. Revision accepted: 9 September 2018.

\begin{abstract}
Amini F, Askary M, Mohtashami F. 2018. Effects of salinity and external proline on seed germination and early growth of Cucumis sativus cv. super ps. Nusantara Bioscience 10: 215-220. Salinity is one of the important abiotic stresses that has an adverse effect on plant productions. High salt concentrations had negative effects on plant processes such as seed germination, seedling growth and turgescent, vegetative growth, flowering and fruiting stages. Proline as a compatible solution plays an important role in defense mechanisms of cellular stress. This study was done to evaluate effects of proline pretreatment $(0$ and $20 \mathrm{mM})$ in terms of salinity $(0,50$, 100 and $150 \mathrm{mM}$ ) on cucumber cv. super ps. The obtained results proved that salinity treatments had significant effects on seed germination rate. On the contrary, application of proline had no significant effect on germination percentages of control and salt-stressed seeds. The root fresh weight and length of plant reduced with salinity increment while proline treatment had positive significant effects on the root dry as well as the fresh weight. Although, no significant variation was found in the root length and dry weight of cultivars treated with proline under salinity stresses. Meanwhile, the shoot length and dry weight of plants declined after salt-stressed treatments. While this condition increased the fresh weight of shoot. Proline treatments increased all of observed parameters but there were no significant variation found in the root length or dry weight of plants treated under saline stresses. The total soluble carbohydrate of plants had positive significant correlation with salt concentration, but the application of proline declined carbohydrate amounts in both salt-stressed and non-stressed plant. Salinity stress increased sodium, proline, protein contents and CAT enzyme, GPOX as well as MDA concentrations, while in the proline-treated plants salinity stresses had no significant effect on CAT, GPOX, MDA concentrations and internal proline amount.
\end{abstract}

Keywords: Cucumis sativus cv. superps, proline, salinity, stress

\section{INTRODUCTION}

Recently, the freshwater availability for agricultural activities is reduced in different parts of the world, because the water needs increase for industries and municipalities activities. Therefore, agriculture procedures face main challenges of using low-quality wastewater and also saline water for crop production. Previous studies (Rhoades et al. 1992: Wan et al. 2010) showed that these unsuitable resources of water for irrigation can be used successfully to grow plants without long-term hazardous consequences to crop plants and soils if suitable strategies of management are applied. The main strategies in this case were; technology of adopting advanced irrigation, selecting appropriately salt-tolerant crop plants, leaching salts under the zone of crop plant root. The salt-tolerant plant uses more or less constant water efficiently. However, it shows a decrease in water use efficiency with salinity increment, especially for the sensitive crops, they decline stronger than the evapotranspiration. This variation can mainly be attributed to various strategies of agronomy, soil as well as water management (Katerji et al. 2003).

Cucumis sativus L. is a species of Cucurbitaceae family. The plant is an annual, fleshy, rather coarse, prostrate or climbing vine. Hisahiro et al. (2008) stated that various parts of this species are used for traditional medicines to treat different disorders such as headache, cooling, and diuretic, nutritive and demulcent, and emetic in acute indigestion in children. In different references, several biological activities of different parts of this plant have shown. The main usage was applied as antidiabetic, antiulcer, moisturizer, antioxidant and analgesic properties (Prashant et al. 2005; Karthiyayini et al. 2009, Swapnil et al. 2012). Furthermore, many investigators (Elisha et al. 1987; Minaiyan et al. 2011) have believed that the extract of its seed was useful in controlling the body weight loss in diabetic rats and also had anti tapeworm's activity. Cytotoxic, antifungal (Joysree et al. 2012) and antibacterial (Tang et al. 2010) activities have been reported from leaves and stem extracts. Phytochemical investigations showed that different components such as cucurbitasides B, C, ferredoxin, $\alpha$ - amyrins, $\beta$-amyrins, and sitosterol were contained in its seeds or leaves (Joshi 2003; Nadkarni et al 2005). Former investigations (e.g. Sivritepe et al. 2003), proved that saline stress decreases plant growth, and this phenomenon may either be due to the decreased availability of water or the toxicity of sodium chloride (Munns et al. 2002).

As yet, different cultivars of Cucumis sativus have been introduced, which are cultivated in different parts of the world. This investigation was designed to identify the proline role in alleviating saline condition in Cucumis sativus cv. super ps by measuring shoot and root dry as well as fresh weight, proline, malondialdehyde (MDA), 
sodium $\left(\mathrm{Na}^{+}\right)$, potassium $\left(\mathrm{K}^{+}\right)$, proline, catalase (CAT) and protein contents in the salt-stressed plant samples supplied with and without proline. For this three suppositions were investigated, they were: (i) examination the effect of salt stresses on biochemical and morphological features of plant, (ii) the proline supply could ameliorate the growth of shoot and root and improved physiological status of plant, (iii) the proline supply could participate with the salt, therewith diminish the toxic reposition of sodium in tissues of plant.

\section{MATERIAL AND METHODS}

This experiment was carried out in Arak University, Arak, Iran. The seeds of Cucumis sativus cv. super ps were cultured in petri dish and placed in the chamber of growth under photoperiod 16/8h (day/night) and temperature of $25^{\circ} \mathrm{C}$. The sterilized seeds were divided into two groups: the seeds of first group were treated with proline $20 \mathrm{mM}$ for $8 \mathrm{~h}$. The other group was soaked in distilled water for $8 \mathrm{~h}$. Afterward, the seeds of both groups were cultured in petri dish under 4 concentrations of $\mathrm{NaCl}$ treatments $(0$, 50,100 and $150 \mathrm{Mm}$ ).

\section{Plant sampling}

Seven days after the salt stress, plant materials were collected. Three plants per treatment were taken to study morphological performances (root and shoot length, dry and fresh weights) and also biochemical contents (CAT, MDP, soluble carbohydrate, protein, proline, sodium and potassium contents) characters.

\section{Plant dry and fresh weight determination}

The treated and control plants were collected, rinsed, blotted and then divided into the shoot and root. For measurement fresh weight of sample, they were directly placed on weighting machine. In order to identify dry weight of plant parts, the divided samples were dried in an oven at $70^{\circ} \mathrm{C}$ for 48 hours. Enough amounts of plant materials were stored for other measurements.

\section{Determination of proline, GPOX, MDA, total soluble carbohydrate and protein content}

The analyses of proline contents were determined using Bates et al. (1973) method. GPOX (glutathione peroxidase) and CAT activities were estimated according to Polle et al. (1994) and Cakmak and Marschner (1992) methods, receptively. In addition, the method of Bradford (1976) was used for estimating the protein content. In this, bovine serum albumin used as the standard. The MDA content was determined using the thiobarbituric acid reaction. The method was described by Heath and Packer (1968). The method of Dubois et al. (1956) was used to measure the amount of total soluble carbohydrate.

\section{Sodium and potassium determination}

The method of Qadar (1995) was used for the extraction and determination of the contents of sodium and potassium. For this, the atomic absorption spectrophotometer (CE
4400 UV VIS Double Deam Scanning Spectrophotometer) was used.

Estimating the rate and mean time of seed germination

By using the following equation the rate of seed germination was determined.

$\mathrm{FPG}=\mathrm{n} / \mathrm{N} \times 100($ Adkins et al. 1984).

Where: $\mathrm{n}$ : the number of germinated seed, $\mathrm{N}$ : total seed number:

The below formula was used to calculate the mean time for seed germination:

$\mathrm{MTG}=\sum(\mathrm{nd}) / \sum \mathrm{n}$

Where: $d$ : the day number, $n$ : total number of germinated seed and $\sum \mathrm{n}$ : total number of germinated seed in the d- day (Ellis and Roberts 1981).

\section{Statistical analyses}

These experiments were arranged as the completely randomized block design with two factors salinity (four levels) and proline (two levels) with three replications. The obtained results were analyzed using SPSS ver. 16 and also excel software.

\section{RESULTS AND DISCUSSION}

\section{Results}

Salinity treatments had significant effects on the seed germination rate. Its lowest amount was recorded in $\mathrm{NaCl}$ $150 \mathrm{Mm}$, while, proline treatment had no significant effect on germination percent of control and salt-stressed seeds. Meantime of seed germination did not change in the stressed plants with $\mathrm{NaC} 150 \mathrm{Mm}$, by the amplification of salinity stresses (100 and $150 \mathrm{mM})$ its time growth by $12.93 \%$ and $34.4 \%$, respectively. Furthermore, significant differences were recorded in the germination mean time of proline-treated seed (Figure 1.A, B).

The fresh weight and length of root reduced with salinity increment (Figure 2.A). Maximum decline of both fresh weight and length of root were observed in $\mathrm{NaCl} 150$ $\mathrm{mM}$. Root dry weight decreased nearly by $33.33 \%$ and $83.33 \%$ in the presence of $\mathrm{NaCl} 100$ and $150 \mathrm{mM}$, respectively. However, treatment with proline had positive significant $(\mathrm{p} \leq 0.01)$ effects on root dry as well as fresh weight. Lengths, fresh and dry weight of shoot in the treated cucumber with proline were increased by $123.43 \%$, $45 \%$, and $100 \%$, respectively.

The decrement of shoot length in the stressed samples with $\mathrm{NaCl} 100$ and $150 \mathrm{mM}$ were nearly $66.19 \%$ and $76.37 \%$, respectively (Figure 2.B). Shoot fresh weight in the presence of $\mathrm{NaCl} 50 \mathrm{mM}$ increased nearly by $139 \%$ in comparison with control plants (Figure 2.C). Although, no significant difference was observed in dry weight of shoot in $\mathrm{NaCl} 100 \mathrm{mM}$, it weight decreased by $66.66 \%$ in the treated cucumber with $\mathrm{NaCl} 150 \mathrm{mM}$. 
No significant variation was found in the root length or dry weight in proline-treated cultivar under salinity stresses. In comparison to untreated plant, the development of root fresh weight in the treated cucumber with proline under salinity $50 \mathrm{mM}$ was $52.3 \%$. While, no significant difference was recorded under salinity stresses 100 and 150 $\mathrm{mM}$. Under $\mathrm{NaCl} 50 \mathrm{mM}$, the treated sample with proline enlarged their shoot nearly by $200 \%$, while other salinity stresses did not have any significant variation compared with control ones. This condition held true for fresh stem weight. This feature in proline- treated cucumber under salinity stress $100 \mathrm{mM}$ was grown by $193.5 \%$.
Concentrations of MDA had a positive significant correlation with salt stresses. Moreover, MDA concentrations were amplified by $44.44 \%$ (in $50 \mathrm{mM}$ ), $77.77 \%$ (in $100 \mathrm{mM}$ ) and also $111.1 \%$ (in $150 \mathrm{Mm}$ ) in the salt-stressed plants.

Significant negative correlations $(\mathrm{p} \leq 0.01)$ were found between protein content of the sample aerial parts with salinity. Its amount decreased under $\mathrm{NaCl} 100$ and $150 \mathrm{mM}$ by $36.34 \%$ and $45.5 \%$, respectively (Figure 3.A). While, salinity had positive affects on the internal proline, therefore, its amount maximized by 34 and $41.11 \%$ at the $\mathrm{NaCl} 100$ and $150 \mathrm{mM}$.

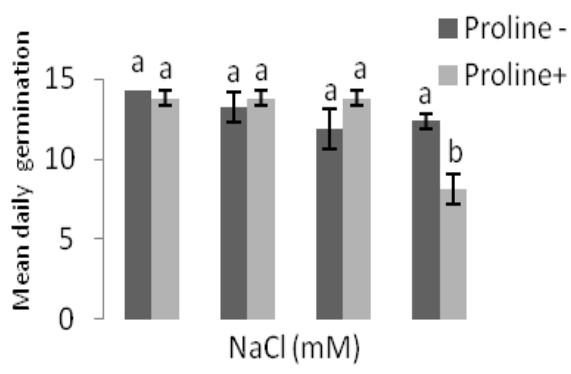

A

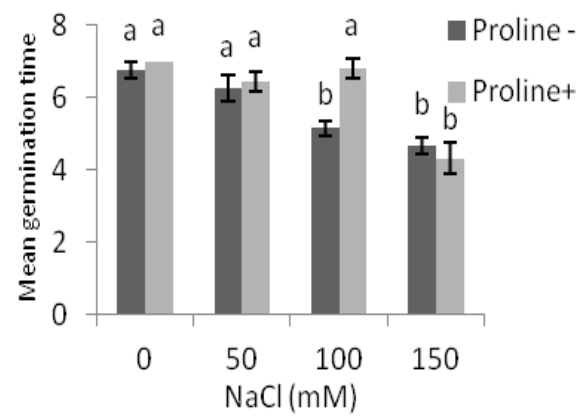

Figure 1. Effects of salinity and proline treatment on seed germination factors

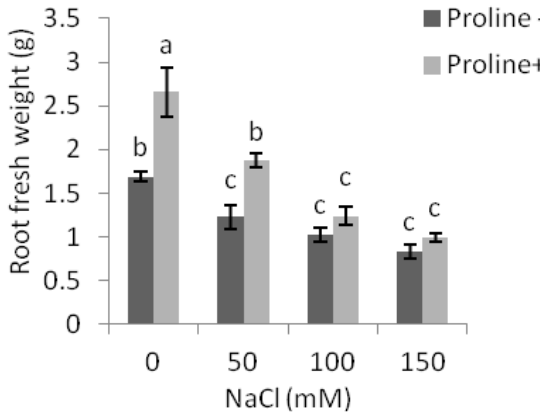

A

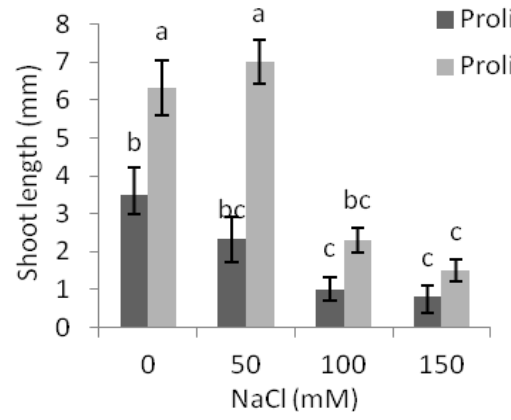

B

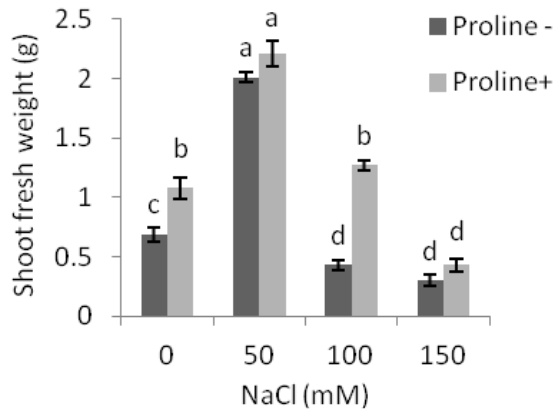

C

Figure 2. Effects of salt stress on morphological traits of proline-treated and untreated plants

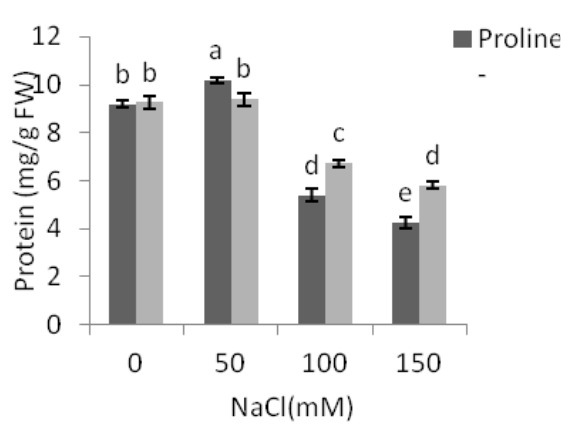

A

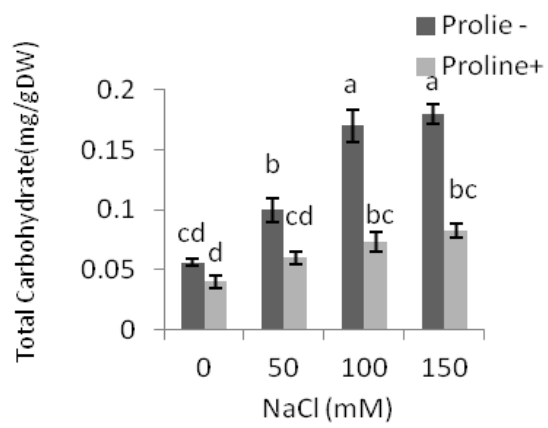

B

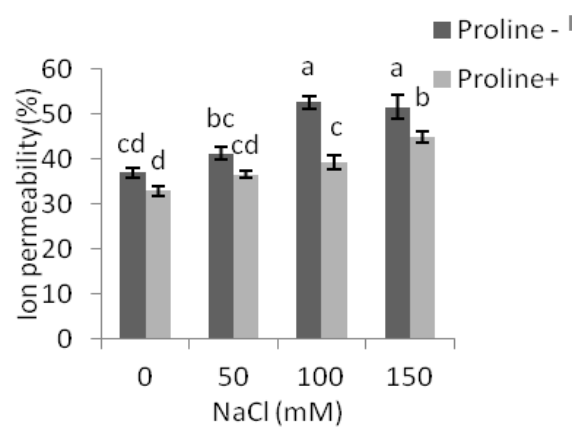

C

Figure 3. Effect of salinity and proline on some biochemical features of Cucumis 
Total soluble carbohydrate had a positive significant correlation with salt concentration. Its amount in $\mathrm{NaCl} 100$ and $150 \mathrm{mM}$ increased by 150 and $171 \%$, respectively. In the proline-treated Cucumis sativus, total carbohydrate declined by $51 \%$. The decrement of carbohydrate amounts of the proline-treated cucumber in 50, 100 and $150 \mathrm{mM}$ of salt stresses were $33.33,37.06$ and $51.53 \%$, respectively (Figure 3.B).

Significant variations $(p=0.01)$ were found between sodium as well as potassium contents of the cell with the increment of salinity stress. On the other hand, the internal sodium content amplified up to $58.27 \%$, while the percentage of potassium was minimized by $32.28 \%$.

Salinity stresses had significant positive effects $(\mathrm{p}=0.01)$ on the contents of internal proline, protein, potassium, CAT enzyme, GPOX as well as MDA concentrations. With increment of salinity, the cell membrane permeability, intercellular sodium, sodium / potassium ratio and also MDA concentrations were minimized compared to control plants (Figure 3.C).

In the proline-treated plants, salinity stresses had no significant effects on CAT, GPOX, MDA concentrations, and internal proline amounts. But, in these plants, saline stresses had a significant impact on potassium and sodium contents, sodium/ potassium ratios, cell membrane permeability, and protein contents. On the fact that, some factors, such as sodium/ potassium ratio, sodium content and cell membrane permeability were diminished, however other mentioned factors were developed.

\section{Discussion}

The obtained results proved that salt stress can affect the overall growth of the plant, either weight or length. The shoot as well as root weights decreased under salinity. In this cultivar, root fresh and also dry weights were more affected than those of the shoot. These findings were in agreement with some previous studies (Mumtaz et al. 2013; Puvanitha and Mahendran 2017; Tunçtürk et al. 2018). The result of these studies showed that the decrease of all plant growth parameters due to decrement in weight of dry root and shoot, and stem elongation. It is important to know that the salt treatment effect was more pronounced on the dry weight of root than dry weight of the shoot. There were several reasons for these conditions, but it seems that the main reason is due to more water loss from the root than shoot during salt stress. Lechno et al. (1997) stated that the negative salt's effect on dry biomass of shoot may be due to stomatal closure, which controls the loss of water from the shoot. Salt treatments make osmotic changes in the tissue of leaves or affect the concentration of leaf $\mathrm{CO}_{2}$ which, leads towards stomata closure. Moreover, elongation of the shoot and root decreased under salinity stresses. This condition amplified with an increment in salt concentration, so plant treated with highest salinity stress had smallest root and shoot. Liu et al. (2015) found that the reduction in root, as well as shoot growth and development, may associate on elongations of cells. These processes may be directly affected by the salt stress.
Salt stress had a positive effect on the concentration of sodium in cell, while its effect on potassium content was reversed. These conditions did not hold true for prolinetreated plant under salinity stresses. The results showed that presence of proline in salinity-treated plants reduced sodium content. These findings were in agreement with Kaya et al. (2007) studies on melon plants. They found that the proline addition benefit is a decline in contents of $\mathrm{Na}+$ in this plant. However, in Huang et al. (2009) study on Cucumis cv. Jinchun No. 2 plants, no decrement of sodium contents were recorded in the proline-treated plant in saline condition.

In salt-stressed cucumber plants, the amount of Malondialdehyde (MDA) increased. MDA is found in the biomembranes, and is the decomposition product of polyunsaturated fatty acids. The compound is used as a lipid peroxidation indicator and studies confirmed that it accumulates under saline condition (Zhu et al. 2008). Our findings confirmed this idea. Elkahoui et al. (2005) reported that the peroxidation of lipids has been associated with the damage provoked by a variety of environmental stresses and this phenomenon is used as line-induced oxidative damage indicator. The addition of proline to either control or under saline samples declined MDA content. Our obtained results confirmed Huang et al. (2009) findings in the Cucumis cultivar "Jinchun No. 2" and also Jain et al. (2001) in Arachis hypogaea L. cell lines. They suggested that application of exogenous proline decreases the MDA amount in salt-stressed samples. It seems that the enhanced salt tolerance of cucumber by exogenous proline is related to lipid peroxidation.

The CAT activity increased with an increment of $\mathrm{NaCl}$ concentration. Although, no significant variation was observed in its activity under moderate salt stress, at presence of $\mathrm{NaCl} 100$ and $150 \mathrm{mM}$ the activity of CAT amplified significantly. However, salt stress did not have a significant effect on the activity of this enzyme in the proline-treated plants. These were concurred with Khedr et al. (2003) observations in Pancratium maritimum L., but did not agree with Huang et al. (2009) findings in Cucumis cv. Jinchun No. 2. They observed that the activity of CAT was not differed by the usage of exogenous proline.

Salinity stress had a positive effect on the non-structural carbohydrate amount. With increment of salinity, the amount of carbohydrates was amplified, while proline contents was decreased. It seems that stress amplifies the dissolved carbohydrate in the plant cell. These findings were in agreement with previous studies. Bartels and Ramanjulu (2005) reported that under saline stress, dissolved carbohydrates, e.g. Sucrose and Hexanes were accumulated. These conditions were observed in several plant species such as tomato (Amini and Ehsanpour 2005) and Hordeum Vulgar L. (Bagheri and Sadeghipour 2009). The increasing of starch hydrolyzes and sucrose synthase are the main reason for the increment of soluble carbohydrates. This process regulates osmosis adjustment in plants which were under environmental stresses. The rate as well as time of seed germination enhanced in saltstressed plant. Former studies on different plant species 
such as Vigna radiate L. and Lens culinaris (Kazerouni et al. 2005), Elymus junceus (Askarian 2004), Sorghum bicolor L. and Pennisetum americanum L. (Khalesro and Aghaalikhani 2006) had similar results. Investigations of Alebrahim et al. (2008) confirmed that reduction of osmotic potential with ionic poisonous is the main reasons.

In our studied Cucumis cultivar, salinity stresses minimized the protein content of the cell, but the application of proline reduced diminution of it. This condition was also observed in different plants such as Helianthus annuus and Colcus blumei (Yu and Rengel 1999), Vicica faba and Amaranthus (Doganlar et al. 2005). Although and Merril (1990) believed that reduction of protein is a prevalent phenomenon in many plant species. However amplification of protein was reported in some species, for example, Gossypium hirsutum L. (Jiang et al. 2005) and Pancratium maritimum (Khedr et al. 2003).

\section{REFERENCES}

Adkins SW, Naylor JM, Simpson GM. 1984, The physiological basic of seed dormancy in Avena fatua. V. Action of ethanol and other organic compounds. Physiol Plant 62: 18-24.

Alebrahim MT, Janmohammadi M, Sharifzadeh F, Tokasi S. 2008. Evaluation of salinity and drought stress effects on germination and early growth of Maize inbred lines (Zea Mays L.). Electronic J Crop Prod 1: 35-43.

Amini F, Ehsanpour AA. 2005. Soluble proteins, proline, carbohydrates, and $\mathrm{Na}+\mathrm{k}+$ changes in two tomato (Lycopersicon esculentum Mill.) Cultivars under in vitro salt stress. Am J Biochem Biotechnol 1: 212 216.

Askarian M. 2004. The effects of salinity and dryness on germination and seedling establishment in Elymus junceus and Kochia prostrate. Pajouhesh and Sazandegi J 64: 71-77.

Bagheri A, Sadeghipour A. 2009. Effects of salt stress on yield, yield components and carbohydrates content in four Hull less Barley (Hordeum vulgare L.) cultivars. J Biol Sci 9: 909-912.

Bartels D, Ramanjulu S. 2005. Drought and salt tolerance in plants. Crit Rev Plant Sci 24 (1): 23-58.

Bates LS, Waldron RP, Teare ID. 1973. Rapid determination of free proline for water-stress studies. Plant Soil 39: 205-207.

Bradford MM. 1976. A rapid and sensitive method for the quantitation of microgram quantities of protein utilizing the principle of protein-dye binding. Anal Biochem 72: 248-254.

Cakmak I, Marschner H. 1992. Magnesium deficiency and high ligh intensity enhance activities of superoxide dismutase, ascorbate peroxidase, and glutathione reductase in Bean leaves. Plant Physiol 98: $1222-1227$

Doganlar ZB, Demir K, Basak H, Gul I. 2010. Effects of salt stress on pigment and total soluble protein contents of three different tomato cultivars. Afr J Agri Res 5: 2056-2065.

Dubois M, Gilles KA. 1956. Colorimetric method for determination of sugars and related substances. Anal Chem 3: 350-354.

Elkahoui S, Hernandez JA, Abdelly C, Ghrir R, Limam F. 2005. Effects of salt on lipid peroxidation and antioxidant enzyme activities of Catharanthus roseus suspension cells. Plant Sci 168: 607-613.

Elisha EE, Twaij HAA, Ali NM, Tarish JH, Al-Omari MM, Karim S 1987.The anti-helmintic activity of some Iraqi plants of the Cucurbitaceae. Pharma Biol 25: 153-157.

Ellis RH, Roberts EH. 1981. The quantification of aging and survival in orthodox seeds. Seed Sci. Technol. 9: 377-409.

Heath RL, Packer L. 1968. Photoperoxidation in isolated chloroplasts. I. Kinetics and stoichiometry of fatty acid peroxidation. Arch Biochem Biophys 125: 189-198.

Hisahiro K, Masaki B, Toru O. 2008. Inhibitory effect of Cucumis sativus on melanin production in melanoma B16 Cells by downregulation of tyrosinase expression. Planta Med 74: 1785-1788.

Huang Y, Bie Z, Liu Z, Zhen A, Wang W. 2009. Protective role of proline against salt stress is partially related to the improvement of water status and peroxidase enzyme activity in cucumber. Soil Sci Plant Nutr 55: 698-704.

Jain M, Mathur G, Koul S, Sarin NB. 2001. Ameliorative effects of proline on salt stress-induced lipid peroxidation in cell lines of groundnut (Arachis hypogaea L.). Plant Cell Rep 20: 463-468.

Jiang L, Duan L, Tian X, Wang B, Li Z. 2005. NaCl salinity stress decreased Bacillus thuringiensis $(\mathrm{Bt})$ protein content of transgenic $\mathrm{Bt}$ cotton (Gossypium hirsutum L.) seedlings. Environ Exp Bot 55: 315320 .

Joshi SG. 2003. Medicinal Plants, Oxford, and IBH Publishing, New Delhi.

Joysree D, Anusua C, Subrata KB, Utpal KK, Syeda RS, Sheikh ZR. 2012. Cytotoxicity and antifungal activities of ethanolic and chloroform extracts of Cucumis sativus Linn (Cucurbitaceae) leaves and stems. Res J Phytochem 6: 25-30.

Karthiyayini T, Rajesh K, Senthil KLK, Sahu RK, Roy A. 2009. Evaluation of antidiabetic and hypolipidemic effect of Cucumis sativus fruit in streptozotocin-induced-diabetic rats. Biomed Pharmacol J 2: 351-355.

Kaya C, Tuna AL, Ashraf M, Altunlu H. 2007. Improved salt tolerance of melon (Cucumis melo L.) by the addition of proline and potassium nitrate. Environ Exp Bot 60: 397- 403.

Lechno S, Zamski E, Tel-Or E. 1997. Salt stress-induced responses in cucumber plants. J Plant Physiol 150: 206-211.

Liu W, Li RJ, Han TT, Cai W, Fu ZW, Lu YT. 2015. Salt stress reduces root meristem size by nitric oxide-mediated modulation of auxin accumulation and signaling in Arabidopsis. Plant Physiol 168 (1): DOI: $10.1104 / \mathrm{pp} .15 .00030$.

Katerji N, van Hoorn JW, Hamdy A, Mastrorilli M. 2003. Salinity effect on crop development and yield, analysis of salt tolerance according to several classification methods. Agric Water Manag 62: 37-66

Kazerouni E, Akramian M, Tokassi S, Eghbali S. 2005. Physiological effects of salt and drought stress on germination and seedling growth of lentil (Lens culinaris) and mungbean (Vigna radiate L.). Hort J 1: 445-448.

Khalesro S, Aghaalikhani M. 2006. Effect of salinity and drought stress on seed germination in forage sorghum (Sorghum bicolor L.) and Pearl millet (Pennisetum americanum L.). Hort J 77: 153-163.

Khedr AHA, Abbas MA, Wahid AAA, Quick WP, Abogadallah GM. 2003. Proline induces the expression of salt-stress responsive proteins and may improve the adaptation of Pancratium maritimum L. to saltstress. J Exp Bot 54: 2553-2562.

Merril CR. 1990. Gel staining techniques. In: Deutscher MP. (ed.). Methods in Enzymology, vol. 182. Academic Press, New York.

Minaiyan M, Zolfaghari B, Kamal A. 2011. Effect of hydroalcoholic and buthanolic extract of Cucumis sativus seeds on blood glucose level of normal and streptozotocin-induced diabetic rats. Iran J Basic Med Sci 14: 436-442.

Mumtaz Khan M, Al-Mas'oudi RSM, Al-Said F, Khan I. 2013. Salinity effects on growth, electrolyte leakage, chlorophyll content and lipid peroxidation in Cucumber (Cucumis sativus L.). Intl Conf Food Agric Sci 55: 6 .

Munns R. 2002. Comparative physiology of salt and water stress. Plant Cell Environ 25: 239-250

Nadkarni AK, Nadkarni KM. 2005. Indian Materia Medica. Popular Prakashan, Bombay, india.

Polle A, Otter T, Seifert F. 1994. Apoplastic peroxidases and lignification in needles of Norway spruce (Picea abies L.), Plant Physiol 106: 5356

Prashant LK, Hemant RJ, Prasad T, Anantha NN. 2005. Cosmetics potentials of herbal extracts. Nat Prod Rad 4: 315-321

Puvanitha S, Mahendran S. 2017. Effect of salinity on plant height, shoot and root dry weight of selected rice cultivars. Sch J Agric Vet Sci 4 (4): 126-131.

Qadar A. 1995. Potassium and sodium content of shoot and lamina of rice cultivars and their sodicity tolerance. J Plant Nutr 18: 2281-2290.

Rhoades JD, Kandiah A, Mashali AM. 1992. The use of saline waters for crop production. In: FAO Irrigation and Drainage, FAO United Nations, Rome, Italy.

Sivritepe N, Sivritepe HO, Eris A. 2003. The effects of $\mathrm{NaCl}$ priming on salt tolerance in melon seedlings grown under saline conditions. Scientia Hort 97: 229-237.

Swapnil S, Jaya D, Meenakshi A, Sarvesh P. 2012. Cytoprotection mediated antiulcer effect of aqueous fruit pulp extract of Cucumis sativus. Asian Pacific J Trop Dis 5: 61-67. 
Tang J, Meng X, Liu H, Zhao J, Zhou L, Qiu M, Zhang X, Yu Z, Yang F. 2010. Antimicrobial activity of sphingolipids isolated from the stems of cucumber (Cucumis sativus L.). Molecules 15: 9288-9297.

Tunçtürk M, Tunçtürk R, Yıldırım B, Çiftçi V. 2011. Effect of salinity stress on plant fresh weight and nutrient composition of some Canola (Brassica napus L.) cultivars. Afr J Biotechnol 10 (10): 1827-1832.

Wan S, Kang Y, Wang D, Liu SH. 2010. Effect of saline water on cucumber (Cucumis sativus L.) yield and water use under drip irrigation in North China. Agric Water Manag 98: 105-113.
Yu Q, Rengel Z. 1999. Drought and salinity differentially influenced activities of superoxidase dismutase in narrow leafed lupine. Plant Sci 142: 1-11.

Zhu J, Bie ZL, Li YN. 2008. Physiological and growth responses of two different salt-sensitive cucumber cultivars to $\mathrm{NaCl}$ stress. Soil Sci. Plant Nutr 54: 400-407. 